Open Access

\title{
Erratum to: Expression profiling of white sponge nevus by RNA sequencing revealed pathological pathways
}

Wenping Cai ${ }^{1 \dagger}$, Beizhan Jiang ${ }^{2 \dagger}$, Tienan Feng ${ }^{3 \dagger}$, Jinfeng Xue ${ }^{4}$, Jianhua Yang ${ }^{5}$, Zhenghu Chen ${ }^{5}$, Junjun Liư ${ }^{5}$, Rongbin Wei ${ }^{5}$, Shouliang Zhao ${ }^{1 *}$, Xiaoping Wang ${ }^{2^{*}}$ and Shangfeng Liu ${ }^{1^{*}}$

\section{Erratum}

After publication of [1] the authors realised that the original publication had two descriptive errors when referring to diseases. "periodontal" was written rather than "mucous membrane" in the article on page 1, lines 12 and 25 . "periodontal disease" was written rather than "mucous membrane hyperkeratosis" in the article on page 2, lines 72 and 73. The correct spelling of these is included in this erratum.

\begin{abstract}
Author details
'Department of Stomatology, Huashan Hospital, Fudan University, Shanghai 200040, P. R. China. ${ }^{2}$ Laboratory of Oral Biomedical Science and Translational Medicine, School of Stomatology, Tongji University, Shanghai 200072, P. R. China. ${ }^{3}$ School of Life sciences and Technology, Tongji University, Shanghai 200065, P. R. China. ${ }^{4}$ State Key Laboratory of Medical Genetics, Central South University, Changsha 410078, P. R. China. ${ }^{5}$ Department of Ophthalmology, Shanghai Tenth People's Hospital, Tongji University School of Medicine, Shanghai 200072, P. R. China.
\end{abstract}

Received: 17 July 2015 Accepted: 17 July 2015

Published online: 23 September 2015

\section{Reference}

1. Wenping C, Beizhan J, Tienan F, Jinfeng X, Jianhua Y, Zhenghu C, et al. Expression profiling of white sponge nevus by RNA sequencing revealed pathological pathways. Orphanet Journal of Rare Diseases. 2015;10:72.

\footnotetext{
* Correspondence: slzhao@tongji.edu.cn; wxp990@hotmail.com; shangfengliufudan@163.com

${ }^{\dagger}$ Equal contributors

'Department of Stomatology, Huashan Hospital, Fudan University, Shanghai 200040, P. R. China

${ }^{2}$ Laboratory of Oral Biomedical Science and Translational Medicine, School of Stomatology, Tongji University, Shanghai 200072, P. R. China
}

\section{Submit your next manuscript to BioMed Central and take full advantage of:}

- Convenient online submission

- Thorough peer review

- No space constraints or color figure charges

- Immediate publication on acceptance

- Inclusion in PubMed, CAS, Scopus and Google Scholar

- Research which is freely available for redistribution 